\title{
The Role of Metaphor in Technical Term-Formation
}

\author{
Hasmik Ghajoyan \\ National Polytechnic University of Armenia
}

\begin{abstract}
Nowadays metaphor is not considered to be a solely literary expressive means. The human mind is both rational and emotional. In terms we both think and act, it is fundamentally metaphorical in nature. Today this idea has gained so wide an acknowledgement that it can be the basis of the contemporary approach to metaphor study. The aim of this article is to analyze the role of terminological metaphor in one specialized field of language, in the process of technical term-formation. The focus is on the field of computing and the respective conclusion that metaphorical transfer is a key process in the formation of technical terms in electronics and information technologies.
\end{abstract}

Key words: metaphor, technical terms, terminological metaphor, conceptual metaphor, metaphorical transfer in computing.

"A metaphor is a kind of magical mental changing room - where one thing, for a moment, becomes another, and in that moment is seen in a whole new way forever."

(James Geary 2012)

\section{Introduction}

The study of metaphor dates back to Aristotle (1927:66) who studied metaphor as a literary device. According to him one of the first classifications of metaphor is to transfer the word changing the meaning from sort to form and from form to sort by analogy. Cicero (in Freidenberg 1996:218) treats metaphor as a way of formation of a meaning which does not exist in language, and the transfer of the meaning on similarity is made because of the absence of the corresponding concept of the word in language.

Modern life is rapidly developing constantly bringing us new ideas, inventions, devices which influence not only our lifestyle but also our language. Technical communication requires knowledge and understanding of some 
technical processes, their components and applications. Thus, we need specific linguistic units and structures which can express conceptual categories. New conceptual structures are frequently described with elements already existing in language.

One of the ways of creating new language structures by means of the existing ones is the metaphorical use of language. By means of metaphor the structures from one conceptual domain are mapped to another, thus making it possible to understand one word by means of another. This process is especially relevant in the formation of terminological metaphors. Terminological metaphor is a new field of investigation which deals to a greater extent with conceptual metaphor.

Lakoff and Johnson (1980:5) as well as Black (1990:153-172) considered metaphor a source of reinforcement of lexical structure of the language. As stated by the authors, it is not possible to do without metaphor even in the language of science. According to them metaphors are part of our everyday life. Metaphors are not only used in language, but they are also used in our thought and actions. Our ordinary conceptual system, in terms we both think and act, is fundamentally metaphorical in nature. The metaphoric thought is a mechanism of thought that is constantly used for communication among people and to the comprehension of the world.

Conceptual metaphors operate in our thought (Lakoff 1993:203). This idea has gained such wide acknowledgement that it can be the basis of the contemporary approach to metaphor study. According to Lakoff and Johnson's traditional distinction, there are three major types of metaphor: conceptual metaphors, metaphorical expressions and image metaphors. The time of political, economic and technological changes have forced people to use powerful linguistic tools to express their thoughts, and the conceptual type of metaphor is considered to be a means to achieve this goal.

\section{Metaphor as a Means of Technical Term-Formation}

Metaphor as a language phenomenon is different from metaphor in artistic speech. Language metaphor is understood first of all as an element of the lexical system of language used by all native speakers as a ready-made means with a definite meaning. Scientific language is precise, strict and devoid of expressiveness and emotiveness. Thus, metaphor in scientific language differs from metaphor in common use. Language metaphor has its specific place in 
terminology, especially in the sphere of electronics and information technologies. Texts concerning these fields are very rich in metaphors as the common words connected with important vital needs which have been created in the course of human activities are penetrating into the world of electronics and information technologies. Most of the terms in these fields are formed by means of narrowing of the meaning of the word and by metaphorical transfer, or metaphorical extension. Thus, for example, the electronic term current has been created by the metaphorical extension or comparison with the current of water, or the current of air on the basis of common characteristics of the concept of movement. Terms are classified according to their denominative peculiarities. If we consider software to be a human being, we will have the metaphorical image of being intelligent, friendly.

Considering the fact that language affects various spheres of human activity (including the activity in the field of electronics and information technologies) we classify metaphors into anthropological and non-anthropological ones. Anthropological metaphors reflect physical, moral and intellectual qualities, and social activities of the human being. Thus, for example some words denoting professions are used as technical terms in their metaphorical meaning. The word actor in common lexicon describes someone who performs in a play, film, etc. (this and other meanings presented in the article are taken from the dictionaries mentioned in the References), while as a technical term it means an objectoriented language developed by the Whitewater Group, Itd. The word administrator describes someone whose job is connected with the management and organization of a company whereas in its metaphorical meaning it denotes a power user who controls everything in a web site. The same can be said in reference to the word agent. It describes a person or company that represents another person or company in business, in their legal problems, while as a technical term it means a program that performs a background task for a user and reports to the user when the task is done, or some expected event has taken place. The names of the parts of the body, words showing relations become technical terms in their metaphorical meaning. Thus, for example the word backbone means the row of a connected bones that go down the middle of your back in its direct meaning, while as a technical term it is used to describe cable segments that connect computers in a straight line. Child means baby, infant in its direct meaning, whereas in its metaphorical meaning it shows a process 
initiated by another process (the parent). Some other examples are illustrated in the table:

\begin{tabular}{|c|c|c|c|}
\hline & Word & Direct Meaning & Metaphorical Meaning \\
\hline 1. & arm & $\begin{array}{l}\text { one of the two long } \\
\text { parts of your body } \\
\text { between your } \\
\text { shoulders and your } \\
\text { hands }\end{array}$ & $\begin{array}{l}\text { it is the long thin part of the } \\
\text { machinery that looks and moves } \\
\text { like an arm }\end{array}$ \\
\hline 2. & body & $\begin{array}{l}\text { the physical structure } \\
\text { of a person }\end{array}$ & $\begin{array}{l}\text { in e-mail and Internet } \\
\text { newsgroups the content of a } \\
\text { message }\end{array}$ \\
\hline 3. & compiler & $\begin{array}{l}\text { someone who } \\
\text { collects different } \\
\text { pieces of information } \\
\text { or facts to be used in } \\
\text { a book, report, etc. }\end{array}$ & $\begin{array}{l}\text { a software program that converts } \\
\text { computer programming } \\
\text { language into machine language } \\
\text { that the computer can interpret }\end{array}$ \\
\hline 4. & compile & $\begin{array}{l}\text { to make a list, record } \\
\text { using different pieces } \\
\text { of information }\end{array}$ & $\begin{array}{l}\text { to put a set of instructions into a } \\
\text { computer in a form that you can } \\
\text { understand and use }\end{array}$ \\
\hline 5. & deselect & $\begin{array}{l}\text { to refuse to choose } \\
\text { an existing Member } \\
\text { of Parliament }\end{array}$ & $\begin{array}{l}\text { to remove something from a list } \\
\text { choices on a computer }\end{array}$ \\
\hline 6. & disarm & $\begin{array}{l}\text { to reduce the size of } \\
\text { your armed forces } \\
\text { and the number of } \\
\text { weapons }\end{array}$ & to transfer to the mode on duty \\
\hline 7. & face & $\begin{array}{l}\text { the front part of the } \\
\text { head from chin to the } \\
\text { forehead }\end{array}$ & one side of a solid object \\
\hline 8. & family & $\begin{array}{l}\text { a group of people } \\
\text { who are related to } \\
\text { each other }\end{array}$ & $\begin{array}{l}\text { a series of hardware or software } \\
\text { products that have some } \\
\text { properties in common }\end{array}$ \\
\hline
\end{tabular}




\begin{tabular}{|c|c|c|c|}
\hline 9. & feed & $\begin{array}{l}\text { to give food to a } \\
\text { person or animal }\end{array}$ & $\begin{array}{l}\text { to advance paper through a } \\
\text { printer device }\end{array}$ \\
\hline 10 . & finder & $\begin{array}{l}\text { someone who finds } \\
\text { something }\end{array}$ & $\begin{array}{l}\text { the standard interface to the } \\
\text { Macintosh. The Finder allows } \\
\text { the user to view the contents of } \\
\text { directories (folders); to move, } \\
\text { copy, and delete files and launch } \\
\text { applications. }\end{array}$ \\
\hline 11. & finger & $\begin{array}{l}\text { to touch or handle } \\
\text { something with your } \\
\text { fingers }\end{array}$ & $\begin{array}{l}\text { to obtain information on a user } \\
\text { by means of the finger program }\end{array}$ \\
\hline 12. & $\begin{array}{c}\text { fingerprint } \\
\text { (v.) }\end{array}$ & $\begin{array}{l}\text { to press someone's } \\
\text { finger on ink and } \\
\text { then press it on the } \\
\text { paper in order to } \\
\text { make a pattern of } \\
\text { lines at the end of the } \\
\text { finger }\end{array}$ & $\begin{array}{l}\text { to scan a computer system to } \\
\text { discover what operating system } \\
\text { (OS) the computer is running }\end{array}$ \\
\hline 13. & fingerprint & $\begin{array}{l}\text { a mark made by the } \\
\text { pattern of lines at the } \\
\text { end of a person's } \\
\text { finger }\end{array}$ & $\begin{array}{l}\text { information embedded or } \\
\text { attached to a file or image to } \\
\text { uniquely identify it }\end{array}$ \\
\hline 14. & handler & $\begin{array}{l}\text { someone who trains } \\
\text { an animal }\end{array}$ & $\begin{array}{l}\text { a routine that manages a } \\
\text { common and relatively simple } \\
\text { condition or operation, such as } \\
\text { error recovery or data movement }\end{array}$ \\
\hline 15 . & handshake & $\begin{array}{l}\text { the act of taking } \\
\text { someone's right hand } \\
\text { and shaking it }\end{array}$ & $\begin{array}{l}\text { a series of signals } \\
\text { acknowledging that } \\
\text { communication or the transfer of } \\
\text { information can take place } \\
\text { between computers or other } \\
\text { devices }\end{array}$ \\
\hline 16. & head & $\begin{array}{l}\text { the top part of your } \\
\text { body }\end{array}$ & $\begin{array}{l}\text { the read/write mechanism in a } \\
\text { disk or tape drive. }\end{array}$ \\
\hline
\end{tabular}




\begin{tabular}{|c|c|c|c|}
\hline 17. & inherit & $\begin{array}{l}\text { to receive money, } \\
\text { property from } \\
\text { someone after they } \\
\text { have died }\end{array}$ & $\begin{array}{l}\text { to acquire the characteristics of } \\
\text { another class, in object-oriented } \\
\text { programming }\end{array}$ \\
\hline 18. & inheritance & $\begin{array}{l}\text { money, property that } \\
\text { you receive from } \\
\text { someone who has } \\
\text { died }\end{array}$ & $\begin{array}{l}\text { the transfer of the characteristics } \\
\text { of a class in object-oriented } \\
\text { programming to other classes } \\
\text { derived from it }\end{array}$ \\
\hline 19. & leader & $\begin{array}{l}\text { the person who } \\
\text { directs or controls a } \\
\text { team }\end{array}$ & $\begin{array}{l}\text { a row of dots, hyphens, or other } \\
\text { such characters used to lead the } \\
\text { eye across a printed page to } \\
\text { related information }\end{array}$ \\
\hline 20. & orphan & $\begin{array}{l}\text { a child whose parents } \\
\text { are both dead }\end{array}$ & $\begin{array}{l}\text { the first line of a paragraph } \\
\text { printed alone at the bottom of a } \\
\text { page or column of text, or the } \\
\text { last line of a paragraph printed } \\
\text { alone at the top of a page or } \\
\text { column. }\end{array}$ \\
\hline 21. & populate & $\begin{array}{l}\text { if an area is } \\
\text { populated by a } \\
\text { particular group of } \\
\text { people, they live } \\
\text { there }\end{array}$ & $\begin{array}{l}\text { 1. to put chips in the sockets of a } \\
\text { circuit board. } 2 \text {. to import } \\
\text { prepared data into a database } \\
\text { from a file using a software } \\
\text { procedure rather than by having } \\
\text { a human operator enter } \\
\text { individual records }\end{array}$ \\
\hline 22. & push & to press a button & $\begin{array}{l}\text { to send data or a program from a } \\
\text { server to a client at the } \\
\text { instigation of the server. }\end{array}$ \\
\hline 23. & thumbnail & $\begin{array}{l}\text { the nail on your } \\
\text { thumb }\end{array}$ & $\begin{array}{l}\text { a miniature version of an image } \\
\text { or electronic version of a page } \\
\text { that is generally used to allow } \\
\text { quick browsing through multiple } \\
\text { images or pages }\end{array}$ \\
\hline
\end{tabular}




\begin{tabular}{|l|l|l|l|}
\hline 24. & widow & $\begin{array}{l}\text { a woman whose } \\
\text { husband has died and } \\
\text { who has not married } \\
\text { again }\end{array}$ & $\begin{array}{l}\text { a last line of a paragraph, shorter } \\
\text { than a full line, appearing at the } \\
\text { top of a page }\end{array}$ \\
\hline
\end{tabular}

Non-anthropological metaphors reflect the reality surrounding the human being. These may be the names of animals, household goods, clothes, plants or trees, and abstract concepts. Metaphorical transfer is carried out from the names of animals to objects. Thus, for example the word mouse means a small furry animal in its direct meaning, while as a technical term it means a common pointing device. This device looked like a mouse with a tail, whereas the cursor on the computer screen is used to be called a CAT, so it was natural that the cat would chase the mouse. Another word apple means a fruit that has a red, light green, yellow skin in its direct meaning, while in its metaphorical meaning it is associated with high end brand apple Mac computers, apple ipads, etc. The word cookie is associated with a flat, dry, sweet cake usually sold in packets, whereas as a technical term it is a block of data that a server returns to a client in response to a request from the client. It is derived from magic cookies which refer to video games where the players had to gain magic cookies in order to advance. The name of the clothing jacket means a short, light coat while as a technical term it denotes the outside covering of a cable or wire. The word bucket as a household goods means an open container with a handle whereas in its metaphorical meaning it describes a region of memory that is addressable as an entity and can be used as a receptacle to hold data. Other examples of nonanthropological metaphors are demonstrated in the table.

\begin{tabular}{|c|c|l|l|}
\hline & Word & \multicolumn{1}{|c|}{ Direct Meaning } & \multicolumn{1}{c|}{ Metaphorical Meaning } \\
\hline 1. & anchor & $\begin{array}{l}\text { a piece of heavy metal } \\
\text { that is lowered to the } \\
\text { bottom of the sea, lake, } \\
\text { etc. to prevent a ship } \\
\text { moving }\end{array}$ & $\begin{array}{l}\text { a format code in a desktop } \\
\text { publishing or word processing } \\
\text { document that keeps an element } \\
\text { in the document }\end{array}$ \\
\hline 2. & bird & $\begin{array}{l}\text { a creature with wings } \\
\text { and feathers that lay } \\
\text { eggs and can fly }\end{array}$ & a satellite \\
\hline
\end{tabular}




\begin{tabular}{|c|c|c|c|}
\hline 3. & boot & $\begin{array}{l}\text { a type of shoe that } \\
\text { covers your whole foot } \\
\text { and the lower part of } \\
\text { your leg }\end{array}$ & $\begin{array}{l}\text { the process of starting or } \\
\text { resetting a computer }\end{array}$ \\
\hline 4. & boot (v.) & $\begin{array}{l}\text { to kick someone or } \\
\text { something hard }\end{array}$ & $\begin{array}{l}\text { to start or reset a computer by } \\
\text { turning the power on }\end{array}$ \\
\hline 5. & branch & $\begin{array}{l}\text { a part of tree that grows } \\
\text { outwards from the } \\
\text { trunk }\end{array}$ & $\begin{array}{l}\text { any connection between two } \\
\text { items such as blocks in a } \\
\text { flowchart or nodes in a network }\end{array}$ \\
\hline 6. & bridge & $\begin{array}{l}\text { a structure built over a } \\
\text { river, road, etc. that } \\
\text { allows people or } \\
\text { vehicles to cross from } \\
\text { one side to the other }\end{array}$ & $\begin{array}{l}\text { a device that connects networks } \\
\text { using the same communication } \\
\text { protocols so that information can } \\
\text { be passed from one to the other }\end{array}$ \\
\hline 7. & briefcase & $\begin{array}{l}\text { a case used for carrying } \\
\text { papers or documents }\end{array}$ & $\begin{array}{l}\text { a system folder in Windows 9x } \\
\text { used for synchronizing files } \\
\text { between two computers, usually } \\
\text { between desktop and laptop } \\
\text { computers }\end{array}$ \\
\hline 8. & bus & $\begin{array}{l}\text { a large vehicle that } \\
\text { people pay to travel on }\end{array}$ & $\begin{array}{l}\text { a set of hardware lines } \\
\text { (conductors) used for data } \\
\text { transfer among the components } \\
\text { of a computer system }\end{array}$ \\
\hline 9. & button & $\begin{array}{l}\text { a small round flat } \\
\text { object on your shirt, } \\
\text { coat }\end{array}$ & $\begin{array}{l}\text { a graphic element in a dialog } \\
\text { box that, when activated, } \\
\text { performs a specified function }\end{array}$ \\
\hline 10. & cell & $\begin{array}{l}\text { the smallest part of a } \\
\text { living thing that can } \\
\text { exist independently }\end{array}$ & $\begin{array}{l}\text { the intersection of a row and a } \\
\text { column in a spreadsheet }\end{array}$ \\
\hline 11. & device & $\begin{array}{l}\text { a plan or trick, } \\
\text { especially for dishonest } \\
\text { purpose }\end{array}$ & $\begin{array}{l}\text { a generic term for a computer } \\
\text { subsystem }\end{array}$ \\
\hline
\end{tabular}




\begin{tabular}{|c|c|c|c|}
\hline 12. & gate & $\begin{array}{l}\text { a frame that you can } \\
\text { open and close to get } \\
\text { through }\end{array}$ & $\begin{array}{l}\text { an electronic switch that is the } \\
\text { elementary component of a } \\
\text { digital circuit }\end{array}$ \\
\hline 13. & jar & $\begin{array}{l}\text { a round glass container } \\
\text { with a wide lid }\end{array}$ & $\begin{array}{l}\text { a file name extension that } \\
\text { identifies a compressed JAR } \\
\text { (Java Archive) file }\end{array}$ \\
\hline 14. & jumper & $\begin{array}{l}\text { a piece of clothing } \\
\text { made of wool }\end{array}$ & $\begin{array}{l}\text { a small plug or wire that can be } \\
\text { connected between different } \\
\text { points in an electronic circuit in } \\
\text { order to alter an aspect of a } \\
\text { hardware configuration }\end{array}$ \\
\hline 15. & plant & $\begin{array}{l}\text { a living thing that has } \\
\text { leaves and roots }\end{array}$ & $\begin{array}{l}\text { the cables that connect all the } \\
\text { computers in a local area } \\
\text { network }\end{array}$ \\
\hline 16. & pine & $\begin{array}{l}\text { a tall tree with long } \\
\text { sharp leaves }\end{array}$ & $\begin{array}{l}\text { one of the most commonly } \\
\text { encountered programs for } \\
\text { reading and composing e-mail } \\
\text { on character-based UNIX } \\
\text { systems }\end{array}$ \\
\hline 17. & pool & $\begin{array}{l}\text { a small area of still } \\
\text { water in a hollow place }\end{array}$ & the dynamic distributed area \\
\hline 18. & port & $\begin{array}{l}\text { a place where ships } \\
\text { stop }\end{array}$ & $\begin{array}{l}\text { an interface through which data } \\
\text { is transferred between a } \\
\text { computer and other devices }\end{array}$ \\
\hline 19. & score & $\begin{array}{l}\text { the number of points } \\
\text { that each team or } \\
\text { player has won in a } \\
\text { game or competition }\end{array}$ & $\begin{array}{l}\text { when referring to a spelling } \\
\text { checker, a score is a number that } \\
\text { indicates how much a } \\
\text { replacement word differs from } \\
\text { the original misspelled word }\end{array}$ \\
\hline 20. & seat & $\begin{array}{l}\text { a place where you can } \\
\text { seat }\end{array}$ & $\begin{array}{l}\text { one workstation or computer, in } \\
\text { the context of software licensing } \\
\text { on a per-seat basis }\end{array}$ \\
\hline
\end{tabular}




\begin{tabular}{|c|c|l|l|}
\hline 21. & seed & $\begin{array}{l}\text { a small hard object } \\
\text { produced by plants }\end{array}$ & $\begin{array}{l}\text { a starting value used in } \\
\text { generating a sequence of random } \\
\text { or pseudorandom numbers }\end{array}$ \\
\hline 22. & shell & $\begin{array}{l}\text { a hard outer part that } \\
\text { covers or protects a nut, } \\
\text { egg, or seed and some } \\
\text { types of animal }\end{array}$ & $\begin{array}{l}\text { a piece of software, usually a } \\
\text { separate program, that provides } \\
\text { direct communication between } \\
\text { the user and the operating } \\
\text { system }\end{array}$ \\
\hline 23. & skyscraper & $\begin{array}{l}\text { a very tall modern city } \\
\text { building }\end{array}$ & $\begin{array}{l}\text { one of several larger formats for } \\
\text { online ads developed to replace } \\
\text { traditional banner ads on the } \\
\text { Internet }\end{array}$ \\
\hline 24. & sink & $\begin{array}{l}\text { a large open container, } \\
\text { especially in a kitchen }\end{array}$ & $\begin{array}{l}\text { a device or part of a device that } \\
\text { receives something from another } \\
\text { device }\end{array}$ \\
\hline 25. & spider & $\begin{array}{l}\text { a small creature with } \\
\text { eight legs which makes } \\
\text { networks of thread for } \\
\text { catching insects }\end{array}$ & $\begin{array}{l}\text { an automated program that } \\
\text { searches the Internet for new } \\
\text { Web documents and indexes } \\
\text { their addresses and content- } \\
\text { related information in a database }\end{array}$ \\
\hline 26. & turtle & $\begin{array}{l}\text { an animal that has a } \\
\text { soft body covered by a } \\
\text { hard shell }\end{array}$ & $\begin{array}{l}\text { a small on-screen shape, usually } \\
\text { a triangle or a turtle shape, that } \\
\text { acts as a drawing tool in } \\
\text { graphics }\end{array}$ \\
\hline
\end{tabular}

Thus, the role of metaphor in technical term-formation is to demonstrate available information transfer which is based on cognitive mechanisms of human memory. The metaphorical terms connect new concepts with the ones which already exist in language, thereby providing maximum efficiency of interaction of common lexicon and technical terms. Terms created by metaphorical transfer are obviously brief, accurate, clear.

\section{Conclusion}

Having analyzed metaphorical terms used in electronics and information technologies we can conclude that these new terms are created from the words 
existing in common lexicon by means of metaphorical transfer. Metaphorical transfer is considered to be a key process in the formation of technical terms in the mentioned spheres. The study shows that a lot of technical concepts have inanimate and inorganic properties, and the metaphors that are used to express these properties frequently become animate and organic. The understanding of unknown concepts by means of the known ones effects our cognitive thinking and creates a basis for new scientific observations and discoveries.

\section{References:}

1. Aristotle (1927) Poetika. Leningrad: Academia.

2. Arutyunova, N.D. (1979) Yazikovaya metafora (sintaksis I leksika). // Lingvistika i poetika. M.: Nauka.

3. Akhmanova, O.S. (2007) Slovar lingvisticheskikh terminov. M.: Komkniga.

4. Black, M. (1990) Metafora. // Teoriya metafori. / Tr. into Russian from English. M.: Progress.

5. Collin, S.M.H. (2004) Dictionary of Computing. GB: Bloomsbury Publishing Plc.

6. Freidenberg, O. (ed.) (1996) Antichniye teorii yazika I stilya. / Tr. into Russian from Ancient Greek and Latin. M.: Russkiye slovari.

7. Geary, J. (2012) I Is an Other: The Secret Life of Metaphor and How It Shapes the Way We See the World. NY: Harper Perennial.

8. Illinguorta, V.; Gleizer E.L.; Payla, I.K. (1989) Tolkoviy slovar' po vychislitel'nym sistemam. M.: Mashinostroenie.

9. Kolisnichenko, D.N. (2009) Anglo russkii tolkovii slovar kompyuternikh terminov. M.: Nauka i tekhnika.

10.Lakoff, G. and Johnson, M. (1980) Metaphors We Live By. Chicago: University of Chicago Press.

11.Lakoff, G. (1993) The Contemporary Theory of Metaphor. Metaphor and Thought. / Ed. by A. Ortony. UK, Cambridge: CUP. 


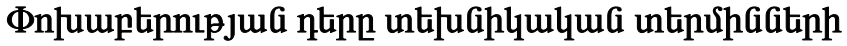

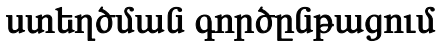

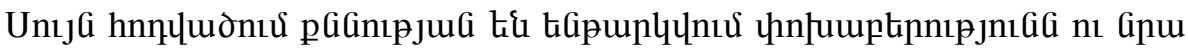

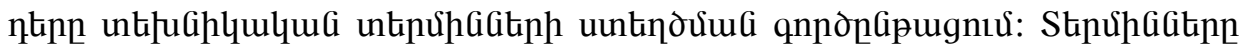

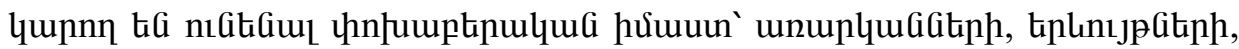

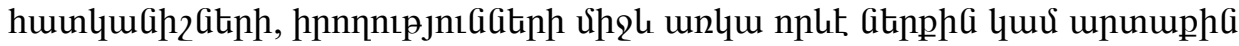

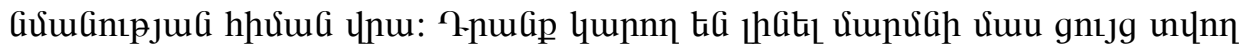

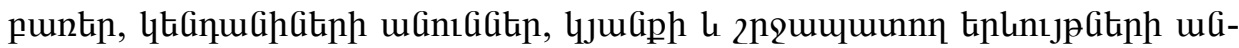

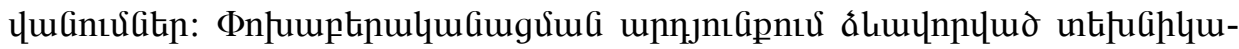

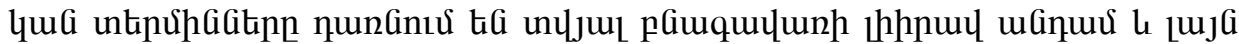

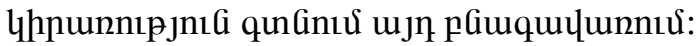

